DOI: 10.22559/folklor.961

Folklor/edebiyat, cilt:25, sayı: 97-1, 2019/1

\title{
4-6 Yaş Arasındaki Çocukların Ebeveynlerinin İstismara Yönelik Farkındalı̆̆ı
}

The Awareness Levels Of Parents Whose Children Ages Between 4 and 6.

$\ddot{O} \mathbf{z}$

\author{
Elif Ünal Bozcan* \\ Bengü Berkmen** \\ Nihan Koran*** \\ Eşmen Tatlıcalı****
}

Bu araştırmanın amacı Kuzey Kıbrıs Türk Cumhuriyeti’nde, okul öncesi eğitim kurumuna devam eden 4-6 yaş arasındaki çocukların ebeveynlerinin istismara yönelik farkındalığını tespit etmektir. Araştırmanın yöntemi tarama araştırmalarından kesitsel taramadır. Araştırmada veri toplama aracı olarak araştırmacılar tarafından geliştirilen Kişisel Bilgi Formu ve Pekdoğan (2017) tarafindan geliştirilen "Ebeveynlere Yönelik İstismar Farkındalık Ölçeği” kullanılmıştır. Araştırmanın evrenini Lefkoşa bölgesinde okul öncesi eğitimi alan 4-6 yaş aralığındaki çocukların ebeveynleri oluşturmuştur. Örneklemini ise evrenden tesadüfi örnekleme yöntemi ile belirlenen ve araştırmaya gönüllü olarak katılan 321 ebeveyn oluşturmuştur. Ebeveynlere Yönelik İstismar Farkındalık Ölçeği ortalamaları ile çalışma grubunun sosyo-demografik özellikleri arasındaki ilişki bağımsız gruplar t Testi ve tek yönlü varyans analizi ile test edilmiştir. Ölçeğin güvenirliğinin hesaplanabilmesi için Cronbach Alfa iç tutarlılık katsayısına bakılmış ve .65 olarak belirlenmiştir. Araştırma verileri SPSS 21.0 programı ile analiz edilmiştir. Araştırma sonucunda 4-6 yaş çocuğu olan ebeveynlerin istismar konusunda orta düzeyde farkındalığa sahip oldukları belirlenmiştir. Elde edilen puanın orta düzeyde olması ebeveynlerin istismar farkındalığının da orta düzeyde olduğunu göstermektedir. Ölçek maddeleri incelendiğinde ebeveynlerin, cinsel istismar konusunda yeterli bilgiye sahip olmadıkları tespit edilmiştir. Çalışmada bazı sosyo demografik değişkenlere göre anlamlı farklar çıkmaması da çocuk istismarının tüm dünyanın yaşadığı bir sorun olduğu ifadesini desteklemektedir. Araştırma sonuçlarına göre, ebeveynler için istismar konusunda farkındalıklarını artırmaya yönelik eğitimlerin düzenlenmesi önerilebilir.

Anahtar sözcükler: 4-6 yaş, ebeveyn, farkındalık, çocuk istismarı, ihmal

\footnotetext{
* Uluslararası Kıbrıs Üniversitesi ebozcan@ciu.edu.tr

** Uluslararası Kıbrıs Üniversitesi, bberkmen@ciu.edu.tr

*** Uluslararası Kıbrıs Üniversitesi nkoran@ciu.edu.tr
} 


\begin{abstract}
The aim of this research is to investigate the awareness of the families about abuse. The families in the target of the research are the families who have children between 4-6 years old. This research was carried out as cross-sectional study. Personal Information Form developed by researchers and Parent Awareness Scale" developed by Pekdoğan (2017) were used as data collection tool. The population of the study was formed by the parents of children between the ages of 4 and 6 who received pre-school education in the Nicosia region. The sample consisted of 321 parents who were randomly sampled and voluntarily participated in the study. The data of the study were analyzed by SPSS 21.0 program. The relationship between the averages of parental abuse awareness scale and the socio-demographic characteristics of the study group were analyzed by t Test and one way ANOVA. For the reliability of the scale Cronbach Alpha was calculated as .65. As a result of the study, it was determined that the awareness level of abuse is medium level. When the scale items were analyzed, it was determined that the parents did not have enough knowledge about sexual abuse. The analyze results of the scales points that the families have medium level of awareness about child abuse. Also the results of the study indicates that the awareness about abuse is not connected with socio demographic issues. According to the results of the study family trainings about child abuse can be recommended.
\end{abstract}

Keywords: 4-6 years old, parent, child abuse, neglect

\title{
Giriş
}

Bu bölümde, çocuk istismarı, aile ve çocuk kavramları hakkında ilgili literatür ışığında yer alan bilgiler ortaya konularak, çocuk istismarı ile ilgili ebeveyn farkındalığının önemi vurgulanmıştır.

Toplumların sağlıklı bir şekilde varlığını sürdürebilmesi için yeni neslin gelişimi büyük önem taşımaktadır. Son yıllarda bu yöndeki engellerin en ciddi olanlarından birisi ise çocuk istismarı olarak karşımıza çıkmaktadır. Çocuk istismarı olgusu, Kempe ve arkadaşları (1962) tarafından yayınlanan Örselenmiş Çocuk Sendromu makalesi ile bilimsel çalışmalarda ilk kez karşımıza çıkmaktadır. Genel olarak çocuk istismarı çocukların gelişimine ve sağlığına zarar veren her türlü, kaza dışı ve önlenebilir davranışlar olarak tanımlanmaktadır. Fiziksel, cinsel, duygusal istismar ve ihmal olmak üzere dört gruba ayrılan istismar çocukların gelişimi açısından risk faktörü oluşturan durumların başında gelmektedir (Polat, 2007). Fiziksel istismar çocuğun kaza dışı yaralanması ve yetişkinlerin çocuğa fiziksel olarak zarar vermesi şeklinde tanımlanmaktadır. Bu istismar türünde çocuğun sağlığını ve gelişimini olumsuz etkileyen, vücutta iz bırakan morluklar ve yaralara rastlanmaktadır. Fiziksel istismar bu özelliği nedeni ile diğer istismar türlerinden daha kolay fark edilebilmektedir (Gil, 1970; Mullen, Martin, Anderson, Romans \& Herbison, 1996). Cinsel istismar ise çocuğun yetişkin tarafindan cinsel 
doyum amaçlı kullanılması olarak açıklanmaktadır. Cinsel istismar yaygın olmasına rağmen gizli tutulma ve vakalarının kapatılması yaygın bir tutum olarak karşımıza çıkmaktadır (Finkelhor, 1994; Gorey \& Leslie, 1997). Duygusal istismar ise çocukları olumsuz etkileyen tutum ve davranışlara maruz kalmasının yanı sıra ilgi, sevgi, bakımdan mahrum bırakılmasıdır. Yaygın olmasına rağmen fiziksel ve cinsel istismar gibi somut bulguların olmaması tespit edilmesini oldukça zorlaştırmaktadır (Glasser, 2002; Polat, 2007). İhmal ise yetişkinin çocuğa karşı yükümlülüklerini yerine getirmemesi olarak ifade edilmektedir. Yetişkinlerin yükümlülüklerini yerine getirmeme durumları sağlık, eğitim, gelişim, beslenme, barınma, güvenli yaşam koşulları gibi alanlarda karşımıza çıkabilmektedir (Gil, 1975; Dubowitz, Black, Starr \& Zuravin, 1993).

İstismarın disiplinler arası görüş birliğine sahip bir tanımının olması önleyici çalışmalar açısından önem taşımaktadır. Böylece istismar ile ilgili çalışan uzmanlar hangi olayların istismar kapsamında değerlendirilebileceğine karar verebilmektedir. Fakat istismarla ilgili uygulamalı çalışmalarda fikir birliğine varmak her zaman kolay olmamaktadır. Çünkü istismar içinde yaşanılan kültürden, yaşantılardan etkilenmektedir. Uzmanlar istismarın kültüre özgü olabileceğini ve kültürden kültüre farklılık gösterebileceğini aktarmaktadır (Polat, 2007; Firmin \& Castle, 2008) . Bazı kültürlerde çocuğa hafifçe vurma, ceza verme disiplin araçlarından biri olarak algılansa da bazı kültürlerde bu davranışlar istismar olarak sınıflandırılmaktadır (Glasser, 2002; Polat, 2007).

İstismar tanımı, oluşumu, şiddeti ve sürekliliği kültürel bağlamda değişiklik göstermesine rağmen, tüm dünyanın temel sorunlarından biridir. Dünya genelinde erken çocukluk dönemindeki çocukların istismara uğrama durumu incelendiği zaman 2-4 yaş arasındaki 300 milyona yakın çocuğun yani her 4 çocuktan 3 'ünün aileleri tarafından disiplin amaçlı istismara maruz bırakıldığı belirtilmektedir. Ayrıca her 10 çocuktan 6'sı da aileleri tarafından fiziksel istismara maruz kalmaktadır (UNICEF, 2017). Halbuki aile; çocuğa hakları ve sorumlulukları hakkında bilgi veren, hak ihlallerinden çocuğun nasıl korunacağını öğreten üyelerden oluşmaktadır. Fakat bazı durumlarda çocukların hakları bu üyeler tarafindan ihlal edilebilmekte ve çocuklar aile içerisinde istismara uğrayabilmektedir. İstismar olgularında çocuklar genelde yakın çevresinde ve tanıdıkları kişilerden zarar görmektedirler. Ayrıca zaman zaman ebeveynler, çocukları üzerinde otorite kurabilmek ve çocuklarını disiplin altına almak için istismara sebep olan davranışlar sergileyebilmektedirler (Gil, 1970; Glaser, 2002). Çocukların erken yaşta hakları ve sorumlulukları ile ilgili bilgilendirilmesi hem çocukların istismardan korunma oranını artırmakta hem de ileride kendisinin ve başkalarının haklarının bilincinde 
olmaları açısından olumlu etki yaratmaktadır. Bu durum ancak çocukların ilk öğretmenleri olan ebeveynleri tarafından bilinçlendirilmeleri ve istismardan arınmış bir aile ortamı hayata geçirilebilmektedir (Ammerman \& Hersen, 1990; Firmin \& Castle, 2008). Ailelerin bunu gerçekleştirebilmesi için hem istismar ile ilgili bilgi ve farkındalığa sahip olması hem de bunu davranışlarına yansıtmayı başarabilmesi gerekmektedir. Bu doğrultuda bu çalışmada 4-6 yaş arasındaki çocukların ebeveynlerinin istismara yönelik farkındalığını saptamak amaçlanmaktadır.

\section{Yöntem}

\section{Araştırma modeli}

$\mathrm{Bu}$ araştırma 4-6 yaş aralığında çocukları olan ebeveynlerin istismar farkındalık düzeylerini belirlemek ve bazı sosyo-demografik özelliklerin bu düzeye etkisinin incelenmesi amacıyla yapılan tarama modelinde betimsel bir araştırmadır. Betimsel araştırma modelinde gerçekleştirilen araştırmalarda varolan durumun saptanması amaçlanmaktadır. $\mathrm{Bu}$ araştırmalarda neden-sonuç ilişkisi ortaya konması amaçlanmamakla birlikte geleceğe yönelik tahmin yürütme durumu da amaçlanmamaktadır (Büyüköztürk, Kılıç Çakmak, Akgün, Karadeniz ve Demirel, 2012; Cohen, Manion, ve Morrison, 2000).

\section{Evren ve örneklem}

Araştırmanın evrenini Lefkoşa'da ikamet eden ve 4-6 yaş çocuğa sahip ebeveynler oluşmaktadır. Araştırmanın örneklemi için Lefkoşa'da bulunan okul öncesi eğitim kurumları ile görüşülmüş ve çalışmanın yapılmasına onay veren kurumlardaki gönüllü veliler arasından tesadüfi örnekleme yöntemiyle seçilmiş 321 ebeveyn ile çalışma tamamlanmıştır.

\section{Veri toplama araçları}

Araştırmada veri toplamak için Demografik Bilgi Formu ve Ebeveynlere Yönelik İstismar Farkındalık Ölçeği Ebeveyn Formu kullanılmıştır.

\section{Demografik bilgi formu}

Araştırmaya gönüllü katılan ebeveynler hakkında bilgi edinmek amacıyla araştırmacılar tarafından oluşturulmuş formdur. Formda katılımcıların yaş, cinsiyet, sahip olunan çocuk sayısı hakkında sorular yer almaktadır.

\section{Ebeveynlere yönelik istismar farkındalık ölçeği ebeveyn formu}


Ölçek 4-6 yaş aralığında çocuğu bulunan ebeveynlerin istismar farkındalık düzeylerini belirleyebilmek amacıyla Pekdoğan (2017) tarafından geliştirilmiştir. Ölçek 18 maddeden oluşan 5'li likert tipi bir ölçme aracıdır. Ölçeğin iç tutarlılık katsayısı .98 olarak bulunmuştur. Ölçme aracından alınabilecek en düşük puan 18, en yüksek puan 90'dır. Buna göre ebeveynin aldığı puan 18-42 aralığında ise düşük, 42-66 puan aralığında ise orta, 66-90 puan aralığında ise yüksek düzeyde istismar farkındalıkları olduğunu göstermektedir. Ölçekten alınan puan yükseldikçe, ebeveynlerin istismar farkındalıklarının yüksek olduğu anlamına gelmektedir.

\section{Verilerin toplanması}

Verilerin toplanması aşamasında öncelikle Lefkoşa bölgesinde yer alan okul öncesi eğitim kurumlarının yöneticileri ile yüz yüze görüşme yapılmıştır. Bu görüşmede yöneticilere araştırmanın amacı ve araştırmada kullanılacak olan veri toplama araçları hakkında bilgi verilmiştir. Yöneticilerin onayının alınmasından sonra yöneticilerden çocukları 4-6 yaş grubuna devam eden ebeveynlerin irtibat numaraları alınmıştır. Ebeveynler aranarak araştırma amacı ile ilgili bilgilendirilmiştir. Araştırmaya katılmak için gönüllü olan ebevenler için veri toplama araçları aydınlatılmış onam formu ile çıktı olarak okul öncesi eğitim kurumlarına bırakılmıştır. Her okul ile veri toplama araçlarının araştırmacılara teslim edilmesi için bir takvimlendirme yapılmıştır. Toplam 350 veri toplama aracından 321'i araştırma kapsamında kullanılmak üzere teslim edilmiştir.

\section{Verilerin analizi}

Ebeveynlerden elde edilen veriler SPSS 21.0 programı ile analiz edilmiş ve Ebeveynlere Yönelik İstismar Farkındalık Ölçeği ortalamaları ile çalışma grubunun sosyo-demografik özellikleri arasındaki ilişki bağımsız gruplar T Testi ve Tek Yönlü Varyans Analizi ile test edilmiştir. Ölçeğin güvenirliğinin hesaplanabilmesi için Cronbach Alfa iç tutarlılık katsayısına bakılmıştır. Yapılan Cronbach Alfa iç tutarlılık analizi sonucunda ölçeğin iç tutarlılık katsayısı .65 olarak belirlenmiştir. Bu da ölçeğin orta düzeyde güvenilir olduğunu göstermektedir.

\section{Bulgular}

“Demografik Bilgi Formu” aracılığıyla çalışma grubuna ilişkin veriler elde edilmiştir. Bu veriler frekans $(f)$ ve yüzde (\%) olarak Tablo 1'de sunulmuştur.

Tablo 1 incelendiğinde çalışma grubundaki katılımcıların \%86.9'u (n=279) kadınlardan, \%13.1'i (n=42) erkeklerden oluşmaktadır. Katılımcıların \% 15.6'sı 20-29 yaş, \%42.7'si (n=137) 30-34 yaş ve \%41.7'si $(n=134) 35$ yaş ve üzerindedir. Katılımcıların sahip oldukları 
çocuk sayılarına bakıldığında ise katılımcıların \% 39.6'sı $(n=127)$ tek çocuk, \%44.9'u (n=144) iki çocuk ve \%15.8'i (n=50) de üç ve üzeri çocuk sahibi olduğunu ifade etmiştir.

Tablo 1. Katılımcıların Sosyo-demografik Özellikleri (N=321)

\begin{tabular}{lll}
\hline & f & \% \\
\hline Cinsiyet & 279 & 86.9 \\
Kadın & 42 & 13.1 \\
Erkek & & \\
Yaş Grubu & 50 & 15.6 \\
$20-29$ & 137 & 42.7 \\
$30-34$ & 134 & 41.7 \\
35 ve üzeri & & \\
Çocuk Sayısı & 127 & 39.6 \\
1 & 144 & 44.9 \\
2 & 50 & 15.8 \\
\hline
\end{tabular}

Çalışmada Ebeveynlere Yönelik İstismar Farkındalık Düzeyi puanlarının araştırmanın değişkenlerine göre farklılaşıp farklılaşmadığını belirlerken parametrik testler kullanılmıştır. Ebeveynlere Yönelik İstismar Farkındalık Düzeyi puanlarının cinsiyete göre farklılık gösterip göstermediğini test etmek için bağımsız gruplar için t-Testi uygulanmış ancak istatistiksel olarak anlamlı bir ilişki bulunamamıştır (Tablo 2).

Tablo 2. Katılımcıların Cinsiyetlerine İlişkin t Testi Sonuçları

\begin{tabular}{lllllll}
\hline Cinsiyet & $\mathbf{N}$ & $\overline{\mathrm{x}}$ & SS & Sd & $\mathbf{t}$ & $\mathbf{p}$ \\
\hline Kadın & 279 & 2.97 & .27 & 50.803 & -1.309 & .266 \\
Erkek & 42 & 3.03 & .31 & & & \\
\hline
\end{tabular}

$* \mathrm{p}<.05$.

Katılımcıların yaşları ve sahip oldukları çocuk sayıları ile Ebeveynlere Yönelik İstismar Farkındalık Düzeyi ortalama puanları tek yönlü varyans analizi ile karşılaştırılmıştır (Tablo 3 ve Tablo 4). K.K.T.C.'de yaşayan ve araştırmaya katılan 4-6 yaş arası ebeveynlerin istismar 
farkındalık düzeyinin yaş, cinsiyet ve sahip olunan çocuk sayısına göre farklılaşıp farklılaşmadığını tespit etmek için tek yönlü varyans analizi yapılmış ancak gruplar arasında anlamlı bir farklılaşma olmadığı bulunmuştur.

Tablo3. Katılımcıların Ölçekten Aldıkları Puanların Yaş Değişkenine Göre Tek Yönlü Varyans Analizi Sonuçları

\begin{tabular}{|c|c|c|c|c|c|c|c|c|c|}
\hline \multicolumn{4}{|c|}{$f, \overline{\mathbf{x}}$, ve s Değerleri } & \multicolumn{6}{|c|}{ ANOVA Sonuçları } \\
\hline Grup & $\mathbf{N}$ & $\overline{\mathbf{x}}$ & $\mathbf{s}$ & & KT & Sd & KO & $\mathbf{F}$ & $\mathbf{p}$ \\
\hline$\overline{20-29}$ & 50 & 3.00 & .30 & G. Aras 1 & .048 & 2 & .024 & .309 & .734 \\
\hline $30-34$ & 137 & 2.97 & .25 & G. içi & 24.553 & 318 & .077 & & \\
\hline 35 ve üzeri & 134 & 2.98 & .29 & Toplam & 24.601 & 320 & & & \\
\hline
\end{tabular}

Tablo 4. Katılımcıların Ölçekten Aldıkları Puanların Sahip Oldukları Çocuk Sayısı Değişkenine Göre Tek Yönlü Varyans Analizi Sonuçları

\begin{tabular}{|c|c|c|c|c|c|c|c|c|c|}
\hline \multicolumn{4}{|c|}{$f, \overline{\mathbf{x}}$, ve s Değerleri } & \multicolumn{6}{|c|}{ ANOVA Sonuçları } \\
\hline Grup & $\mathbf{N}$ & $\overline{\mathbf{x}}$ & $\mathbf{s}$ & & KT & Sd & KO & $\mathbf{F}$ & $\mathbf{p}$ \\
\hline Tek çocuk & 127 & 2.99 & .25 & G. Aras1 & .038 & 2 & .019 & .247 & .781 \\
\hline İki çocuk & 144 & 2.97 & .28 & G. içi & 24.562 & 318 & .077 & & \\
\hline Üç ve üzeri & 50 & 2.96 & .32 & Toplam & 24.601 & 320 & & & \\
\hline
\end{tabular}

Katılımcıların ölçek maddelerine verdikleri ortalama puanlar incelendiğinde, katılımcıların yanıtlarında 1.28 ortalama puan ile en düşük ortalama puan “Madde 12: Çocuğumda darp izleri görürsem, çocuğuma sorup nasıl olduğu hakkında bilgi alırım” maddesine verilmiştir. Bir başka sonuç da katılımcıların 4.30 ile en yüksek ortalama puan verikleri " :Madde 14: Çocuğuma çok sinirlendiğim zaman ona bu davranışının beni rahatsız ettiğini söylerim.” ölçek maddesidir.

Tablo 5. Katılımcıların Ölçek Maddelerine Verdikleri Puan Ortalamaları

\begin{tabular}{lc} 
Maddeler & Ortalama Puan \\
\hline Madde 1 & 1.60 \\
Madde 2 & 3.14 \\
Madde 3 & 1.96 \\
Madde 4 & 4.01 \\
Madde 5 & 2.59 \\
Madde 6 & 4.01 \\
Madde 7 & 3.60 \\
Madde 8 & 3.17
\end{tabular}


Madde 9

Madde 10

Madde 11

Madde 12

Madde 13

Madde 14

Madde 15

Madde 16

Madde 17

3.63

Madde 18

Bununla birlikte katılımcıların cinsel içerikli 3 soruya çelişkili yanıtlar verdikleri dikkat çekmektedir. Buna göre katılımcılar "Madde 7:Çocuğum tv izlerken cinsel içerikli sahnelerde televizyonu kapatır ya da kanal değiştiririm.” maddesine ortalama 3.60; “ Madde 8:Çocuğum tv izlerken cinsellik, şiddet vb. sahnelerde çocuğumun doğru bilgilenmesi için sesli yorum yaparım.” maddesine ortalama 3.17 ve “ Madde 9: Çocuğum tv izlerken cinsellik, şiddet vb. sahnelerde çocuğum cinsellik, şiddet vb. sahnelerden etkilenmemesi için uyuduktan sonra tv açarım." maddesine ise ortalama 3.29 puan vermişlerdir.

Araştırmada ayrıca katılımcıların ölçme aracından aldıkları toplam puanlara bakılmıştır. Katılımcıların puanlarının 42-66 aralığında olduğu belirlenmiştir. Ebeveynlere Yönelik İstismar Farkındalık Ölçeği’ne göre 42-66 puan aralığı orta düzeyde istismar farkındalıkları olduğunu göstermektedir.

\section{Sonuç ve tartışma}

İstismar çocuğun tüm gelişimine zarar veren kaza dışı ve önlenebilir davranışlar olarak tanımlanmaktadır. Fiziksel, duygusal, cinsel istismar ve ihmal olarak dört ana gruba ayrılan istismar son y1llarda tüm dünyada üzerinde durulan, ciddi boyutlara ulaşan toplumsal bir sorun olarak karşımıza çıkmaktadır (Polat, 2007). Dünya Sağlık Örgütü (2013) 1000 çocuktan ortalama 9'unun ihmal ve istismara uğradığını belirtmektedir. UNICEF'in (2017) verilerine göre de dünya genelinde, 2-4 yaş arasındaki 300 milyona yakın çocuğun yani her 4 çocuktan 3'ünün aileleri tarafından disiplin amaçlı istismara maruz bırakıldığı belirtilmektedir. Ayrıca her 10 çocuktan 6'sı aileleri tarafından fiziksel istismara maruz kalmaktadır. Bu bağlamda, Birleşmiş Milletler Çocuk Hakları Sözleşme'sinde çocukların, ebeveynlerinin veya diğer 
yetişkinlerin fiziksel ve/veya psikolojik şiddetinden korunması gerektiği vurgulanmış, konu Birleşmiş Milletler Topluluğu'na üye tüm ülkelerin dikkatine sunulmuştur. (Oral, Engin ve Büyükyazıcı 2010; Dünya Sağlı Örgütü, 2013).

Çocuk istismarı olgusu, Kempe ve arkadaşları (1962) tarafindan yayınlanan "Örselenmiş Çocuk Sendromu” isimli makale ile bilimsel çalışmalarda ilk kez karşımıza çıkmaktadır. Bu dönemde yapılan çalışmalar çocuğa yönelik istismarın tüm ülkelerde ve kültürlerde olabileceğine vurgu yapmıştır. Yapılan çalışmalar çocuk istismarının sıklıkla okul öncesi dönemde ve aile üyeleri ile öğretmenler tarafından gerçekleştirildiğini ortaya koymaktadır. İstismar vakalarını araştırmanın en önemli zorluğunun da bundan ve yeterli değerlendirme araçlarının olmayışından kaynaklandığı görülmektedir (Bilir, Dönmez, Güneysu, 1991; Tan, 1991; Taner ve Bahar 2004). Çocuk istismarında özellikle yakın çevrenin etkilerinin görülmesi son derece çelişkili ve inanılması zor bir durum olsa da istatistiksel veriler bu gerçeği açık bir biçimde gözler önüne sermektedir. Bununla birlikte son 10 yılda çocuk istismarına yönelik vakaların artması da bu gerçeğe daha çok dikkat çekmektedir (İnsan Hakları Derneği, 2018; Türkiye'de Çocuk İstismarı Raporu, 2018). Aile üyeleri çoğunlukla yaratacakları uzun veya kısa vadeli zararların farkına varmadan çocuklarının gelişimlerini olumsuz şekilde etkileyebilecek istismara yönelik tutum ve davranışlar sergileyebilmektedirler. Aile içinde anne ve babaların çocuk yetiştirme anlayışları kendi çocukluk yaşantılarından, aile yapılarından, kültürlerinden, sosyo-ekonomik özelliklerinden, eğitim düzeylerinden güçlü bir biçimde etkilenmektedir. Aynı zamanda aile içi şiddet, tek ebeveynli yaşam, zayıf anne-baba ve çocuk ilişkisi, ebeveyn bağımlılığı vb. faktörlerin çocuğa yönelik istismara zemin hazırladığı belirtilmektedir (Bilir, Arı, Dönmez \& Güneysu, 1991; Güler, Uzun, Boztaş \& Aydoğan 2002; Özmen, 2004; Polat, 2007; Bahar, Savaş \& Bahar, 2009)

Araştırmanın sonuçları göz önüne alındığında ebeveynlerin çocuk istismarına yönelik farkındalıklarının orta düzeyde olması ile farkındalık düzeyinin yaş, cinsiyet ve sahip olunan çocuk sayısına göre farklılaşmamasına yönelik bulgular bazı alan yazın çalışmalarıyla desteklenmekte, bazılarıyla farklılaşmaktadır. Yalçın, Koçak ve Duman (2014) tarafından anne babaların çocuk istismarıyla ilgili tutumlarının incelenmesi amacıyla yapılan çalışmanın sonucunda çalışmaya katılan toplam 107 anne ve babanın duygusal istismar farkındalıklarının istatistiksel olarak anlamlı düzeyde farklılaşmadığı belirlenmiştir. Çalışmada ayrıca anne ve babaların istismar farkındalık puanlarının düşük düzeyde olduğu belirlenmiştir. Dallar Bilge ve arkadaşları (2013), alt sosyoekonomik düzeye sahip anne-babaların çocuk istismarı ve ihmali 
hakkındaki bilgi düzeyleri, deneyimleri ve kullandıkları disiplin yöntemlerini araştırdıkları çalışmada, 1043 ebeveynle çalışmışlardır. Çalışma sonunda ebeveynlerin ihmal ve istismara yönelik tutumlarının cinsiyetlerine göre farklılaşmadı̆̆ı, eğitim ve gelir düzeylerine göre ise farklılaştığı saptanmıştır. Bilir ve arkadaşları (1991) ve Hancı (2008) çocuk istismarı ile ilgili çalışmalarında, ailenin düşük eğitimli olmasını önemli bir risk faktörü olarak belirtmişlerdir. Bilir ve arkadaşlarının (1991) çalışmasında ayrıca, ailede sahip olunan çocuk sayısı arttıkça istismarın da arttığı yönde bulgulara ulaşılmıştır. Bulut (1996), Güler, Uzun, Boztaş, Aydoğan (2002) ve Yunusoğlu (2007) istismarın ebeveynin cinsiyetiyle olan ilişkisinden bahsederek, anne ve babanın çocuklarına yönelik istismar tutumlarının farklılık gösterdiğini belirmişlerdir. Yapılan araştırmada elde edilen bulgular genel olarak istismarın her aile ortamında gerçekleşebileceğini ortaya koymaktadır. Bu sonuç her ailenin konu ile ilgili bilgilendirmesi için eğitim almasının önemini bir kez daha ıspatlamaktadır. Zaman zaman aileler için sadece eğitim hizmetleri yeterli olmamakta psikolojik destek hizmetlerine de ihtiyaç duyulabilmektedir (Polat, 2007). Ayrıca yapılan araştırmalarda (Vatansever, Duran, R. Yolsal, 2004; Kara, Biçer, Sevim Gökalp, 2004; Kocaer, 2006; Yunusoğlu, 2007; UNICEF, 2017; Kars, 2018), cinsel istismarın, istismar vakalarında azımsanmayacak düzeyde olduğu belirtilmektedir. $\mathrm{Bu}$ veriler araştırmadaki, ebeveynlerin cinsel istismar veya cinsel eğitime ilişkin konularda nasıl davranacakları ile ilgili net olmadıklarına ilişkin bulguyu önemli kılmaktadır. Bununla birlikte ebeveynlerin ölçekte yer alan cinsel içerikli 3 soruya çelişkili yanıtlar vermeleri de dikkat çekmektedir. Bu sonuç katılımcıların cinsel istismar veya cinsel eğitime ilişkin konularda nasıl davranacakları ile ilgili net olmadıklarını düşündürmektedir. Cinsel istismar ile birlikte çocukta cinsel gelişim halen daha aile içinde konuşulmaktan kaçınılan ve tabu oluşturan bir konu olarak karşımıza çıkmaktadır. Çocuğun cinsel istismardan korunması için yetişkinler tarafından konu ile ilgili bilgilendirilmesi önem taşımaktadır. Geçmişte çocuğun bilinçlendirilmesinde cinsel organlarına yönelik eylemler göz önünde bulundurulmaktayken günümüzde çocuğun beden bütünlüğüne dikkat çekilmektedir. $\mathrm{Bu}$ konuda önemli olan nokta çocuğun cinsel istismara maruz kalması durumunda bunu güvendiği bir yetişkine anlatabilmesi ve destek hizmetlerinden yararlanabilmesidir. Aslında ulaşılmak istenen nokta çocuğun kendini istismardan koruyabilmesi için eğitim almasıdır. Bunun gerçekleşmesi için de ailelerin çocuklarla bu bilgileri paylaşması gerekmektedir. Fakat bu konuda yeterli bilgiye sahip olmayan aileler çocuğu yanlış bilgilendirebilmektedir. Örneğin aileler çocuğa yabancı biri ile birlikte gitmemesini ya da karanlık ve ıssız yerlerde yalnız kalmamasını öğütlemektedir. Fakat bu ögütlerin aksine istismarcılar genelde çocuğun tanıdığı kişiler olmakla birlikte çocuğun zaman geçirdiği ortamlarda gerçekleşmektedir (Singh, 
Parsekar \& Nair, 2014; Maree \& Venter; Polat, 2007). Bakır ve Kapucu (2017) tarafindan Türkiye'de yapılmış olan ve çocuk ihmal ve istismarını konu alan araştırmaların incelendiği çalışmaya göre, bu konuda yapılmış olan çalışmaların özellikle son 10 yılda artış gösterdiğine dikkat çekilmektedir. Çalışmada ayrıca, çocuk istismarının belirlenebilmesi için kullanılan tarama araçlarının düşük kalitede olduğunu belirten araştırmalara ve en az çalışılan örneklemin “aile” olduğuna dikkat çekilmiştir. Bu anlamda bu çalışmanın verilerinin araştırma sonuçlarına katkı sağladığı söylenebilir. Çünkü çocuk istismarına yönelik farkındalığın gittikçe arttığı, farkındalığın aile ile başladığı ve ailenin en önemli kilit nokta olduğu dikkate alındığında, aile bireylerinin farkındalıkları daha da önem kazanmaktadır.

Ebeveynlere uygulanan ölçek sonuncunda en düşük puan ortalamasının "Çocuğumda darp izleri görürsem, çocuğuma sorup nasıl olduğu hakkında bilgi alırım" maddesine ait olduğu saptanmıştır. Buna göre katılımcıların böyle bir durumda olayın nasıl gerçekleştiğini çocuğa sormama eğilimde oldukları düşünülmektedir. $\mathrm{Bu}$ durum araştırmacılara üç olasılığı düşündürmektedir. Birinci olasılık ailelerin olayın nasıl gerçekleştiğini bildiğinden dolayı çocuğa soru sormama eğiliminde olmalarıdır. Yani çocuktaki darp izinin kaynağı aile olabileceği gibi aile üyelerinin de tanıklık ettiği bir durum olabilmektedir. İkinci olasılık ise ailelerin fiziksel istismara yönelik bulguların kaynağını araştırmamasının fiziksel istismarı önemsemediklerinden kaynaklandığı yönündedir. Üçüncü bir olasılık ise ailenin fiziksel istismar davranışını sergileyen kişi ile ilgili yüzleşmekten kaçınması olabileceğidir. Zaman zaman aile fiziksel istismarın kaynağını bilmekte fakat çeşitli nedenlerden dolayı bu davranışı sergileyen kişi ile ilgili konu hakkında konuşmaktan kaçınmaktadır (Barnett, Miller-Perrin \& Perrin, 2005; Coohey \& Braun, 1997; Kellogg, 2007). .Bir başka sonuç da katılımcıların 4.30 ile en yüksek ortalama puan verdikleri "Çocuğuma çok sinirlendiğim zaman ona bu davranışının beni rahatsız ettiğini söylerim.” ölçek maddesidir. Bu sonuç katılımcıların çocuklarıyla yaşadıkları olumsuz durumlarda karşılıklı iletişim kurma ve "ben dili" ni kullanmaya yönelik tutumlar sergileme eğiliminde olduklarını düşündürmektedir. Bu yanıt ailelerin çocuk ile sağlıklı iletişim kurma yönünde davranış sergilediklerini ortaya koymaktadır sözel olarak çocukları duygusal istismara maruz bırakma davranışından uzaklaştıklarını göstermektedir.

Araştırmada kullanılan Ebeveynlere Yönelik İstismar Farkındalık Ölçeği'nin iç tutarlılık katsayısının .65 düzeyinde çıkmış olması; araştırmaya katılan ebeveynlerin istismara ilişkin fikirlerini ortaya koymakta yaşadıkları çelişkili tutumlar veya istismarın çok fazla tartışılabilir bir kavram olmayışı şeklinde yorumlanabilmektedir. Yukarıda belirtildiği gibi 
istismar konusunda yapılan çalışmalar hala çok azdır ve genellikle istismarı gerçekleştirenler aile üyeleridir. Bu nedenle anne ve babaların bu konudaki hassasiyetleri, tedirginlikleri ve çok fazla konuşulmak istenen bir durum olarak tercih edilmemesi bu sonucu doğurmuş olabilir.

Kıbrıs Türk toplumunun çocuğa değer veren imaja sahip olması ve çocuğun ailedeki yeri dikkate alındığında (Eser, 2016), araştırmanın ulaştığı sonuçların, ebeveynlerin çocuk istismarına yönelik farkındalıklarının beklenen düzeyden düşük olduğu söylenebilir. $\mathrm{Bu}$ anlamda araştırmadan çıkan sonuçlar ve incelenen literatür 1şığında uygulayıcılara ve araştırmacılara yönelik olarak aşağıdaki öneriler sunulmuştur.

- Ebeveynlerin çocuk istismarı farkındalığı orta düzeydedir. Bu nedenle Kıbrıs Türk Toplumunda çocuk istismarına yönelik bilgilendirici çalışmalar planlanarak arttırılabilir. Bu konuda sosyal medya bir aracı olarak kullanılabilir.

- Ebeveynlere yönelik yerel yönetimler tarafından çocuk istismarı konusunda aile eğitimleri düzenlenebilir.

- Ebeveynlerin çocuk istismarı durumunda izlenmesi gereken adımlar ile ilgili bilgilendirilmesine yönelik çalışmalar planlanabilir.

- Ebeveynlerin çocuk istismarına ilişkin bazı sorulara (cinsel içerikli) çelişkili cevap verdikleri dikkate alındığında, özellikle cinsel istismar konusunda yapılacak çalışmalara yer verilmesi önerilebilir.

- Çalışma nicel yöntemlerle birlikte, gözlem ya da görüşme gibi nitel yöntemleri de içeren karma bir çalışma şeklinde yapılabilir.

- İstismar farkındalığına yönelik çalışmalar farklı kültürlerde yapılarak sonuçları karşılaştırılabilir.

- Örneklem grubu genişletilerek, çalışmaya öğretmenler ve çocuklar da dahil edilebilir.

\section{Kaynaklar}

Ammerman, R. T. \& Hersen, M. (1990). Children at risk. An evulation offactors contributing to child abuse and neglect. New York: Plenum Pres.

Bahar, G., Savaş, A. H, Bahar, A. (2009). Çocuk istismarı ve ihmali: Bir gözden geçirme. Fırat Sağllk Hizmetleri Dergisi, 12(4): 51-65.

Bakır, E., Kapucu, S. (2017). Çocuk ihmali ve istismarının Türkiye'de yapılan araştırmalara yansıması: Bir literatür incelemesi. Hacettepe Üniversitesi Hemşirelik Fakültesi Dergisi, 4(2), 13-24. 
Barnett, O., Miller-Perrin, C. L., \& Perrin, R. D. (2005). Family violence across the lifespan: An introduction. Sage Publications, Inc.

Bilir, Ş., Ar1 M., Dönmez, N., Güneysu, S. (1991). 4-12 yaşları arasında 16.100 çocukta örselenme durumlarl ile ilgili bir inceleme, (Editör: Konanç, E., Gürkaynak, İ., Egemen, A.). Çocuk İstismarı ve İhmali. Ankara: Gözde Repo Ofset

Bulut, I. (1996). Genç anne ve çocuk istismart. Ankara: Bizim Büro.

Büyüköztürk, Ş., Kılıç Çakmak, E., Akgün, Ö. E. , Karadeniz, Ş., ve Demirel, F. (2012). Bilimsel araştırma yöntemleri. Ankara: Pegem A.

Cohen, L., Manion, L. ve Morrison, K. (2000). Research methods in education. London New York: Routledge Falmer.

Coohey, C., \& Braun, N. (1997). Toward an integrated framework for understanding child physical abuse. Child Abuse \& Neglect, 21(11), 1081-1094.

Çocuk Haklarının Desteklenmesi ve Korunmasına İlişkin AB Kılavuz İlkeleri (2017). 15.04.2018.https://www.avrupa.info.tr/sites/default/files/201704/EU\%20Guidelines\% 20Rights\%20of\%20Child_v5e.pdf.

Çocuk Haklarına Dair Sözleşmenin Onaylanmasının Uygun Bulunmasına İlişkin Yasa. (1996). 12.12.2018 http://www.mahkemeler.net

Eser, B. (2016). Kuzey Kıbrısta ailede çocuğun değerinin aile yapıları açısından incelenmesi. (Yayınlanmamış Yüksek Lisans Tezi). DAÜ Lisansüstü Eğitim Öğretim ve Araştırma Enstitüsü, Gazi Magosa.

Finkelhor, D. (1994). The international epidemiology of child sexual abuse. Child abuse \& neglect, 18(5), 409-417.

Firmin, W. M. ve Castle, L. S. (2008). Early childhood dicipline: A review of the literature. Journal of Research on Christian Education.17, 107-129.

Güler, N., Uzun, S., Boztaş, Z. ve Aydoğan, S. (2002). Anneleri tarafindan çocuklara uygulanan duygusal ve fiziksel istismar/ihmal davranışı ve bunu etkileyen faktörler. Cumhuriyet Üniversitesi Tıp Fakültesi Dergisi. 24, (3), 128-134.

Dallar Bilge.Y., Taşar, M. A., Kılınçoğlu, B., Özmen, S., \& Tıraş, Ü. (2013). Alt sosyoekonomik düzeye sahip anne-babaların çocuk istismarı ve ihmali hakkındaki bilgi düzeyleri, deneyimleri ve kullandıkları disiplin yöntemleri. Anadolu Psikiyatri Dergisi; 14:27-35

Dubowitz, H., Black, M., Starr Jr, R. H., \& Zuravin, S. (1993). A conceptual definition of child neglect. Criminal Justice and Behavior, 20(1), 8-26.

Dünya Sağlık Örgütü. (2013). European report on preventing child maltreatment, 20.04.2018. http://www.euro.who.int/_data/assets/pdf_file/0019/217018/European-Report-onPreventing-Child-Maltreatment.pdf

Glaser, D. (2002). Emotional abuse and neglect (psychological maltreatment): A conceptual framework. Child Abuse \& Neglect, 26(6-7), 697-714. 
Gil, D. G. (1970). Violence against children: Physical child abuse in the United States (Vol. 6). Cambridge, MA: Harvard University Press.

Gil, D. G. (1975). Unraveling child abuse. American journal of Orthopsychiatry, 45(3), 346.

Gorey, K. M., \& Leslie, D. R. (1997). The prevalence of child sexual abuse: Integrative review adjustment for potential response and measurement biases. Child Abuse \& Neglect, 21(4), 391-398.

Hancı, H. (2008). İzmir'de eğitim hastanelerinde çocuk istismarı tanısı alan olgularla ilgili İzmir çocuk istismarı araştırma grubunun on sekiz aylık deneyimi. 20.04.2018. http://www.sosyalhizmetuzmani.org/cocukistismari.htm

İnsan Hakları Derneği (2018). İHD: Türkiye cinsel istismarda 3. Sırada, 16 yılda 440 bin çocuk doğum yaptı. 12.12.2018. https://tr.sputniknews.com/turkiye/201806101033803155ihd-turkiye-cinsel-istismar-cocuk-dogum/

Kara, B., Biçer, Ü. \& Sevim Gökalp, A. (2004). Çocuk istismarı. Çocuk Sağlı̆̆ı ve Hastalıkları Dergisi. 47: 140-15

Kars, Ö. (2018). Çocuk istismarına karşı farkındalık. 20.04.2018. http://www.aydin24haber.com/cocuk-istismarina-karsi-farkindalik-363987h.htm

Kempe C, H, Silverman F, N, Steele B, F, Droegemueller W, Silver H, K. (1962). The batteredchild syndrome. JAMA.1962;181(1):17-24. doi:10.1001/jama.1962.03050270019004

Kellogg, N. D. (2007). Evaluation of suspected child physical abuse. Pediatrics, 119(6), 12321241.

Kocaer, Ü. (2006). Hekim ve hemşirelerin çocuk istismarl ve ihmaline yönelik farkındalı düzeyleri, (Yayınlanmamış Yüksek Lisans Tezi), Marmara Üniversitesi, İstanbul.

Maree, J. G., \& Venter, C. J. (2018). Improving the career resilience of a survivor of sexual abuse. Early Child Development and Care, 188(2), 240-249.

Mullen, P. E., Martin, J. L., Anderson, J. C., Romans, S. E., \& Herbison, G. P. (1996). The long-term impact of the physical, emotional, and sexual abuse of children: A community study. Child abuse \& neglect, 20 (1), 7-21.

Özmen, K. S. (2004). Aile içinde öfke ve saldırganlığın yansımaları. Ankara Üniversitesi Ĕ̈itim Bilimleri Fakültesi Dergisi.37: 27-39.

Pekdoğan, S. (2017). İstismar farkındalık ölçeği ebeveyn formu: ölçek geliştirme çalışması. Akademik Bakış Dergisi. 62, 173-185.https://www.researchgate.net/publication/319528926_Istismar_Farkindalik_Olcegi_Eb eveyn_Formu_Olcek_Gelistirme_Calismasi

Polat, O. (2007). Çocuk istismarı tanımlar 1. İstanbul: Seçkin Yayıncılık.

Singh, M. M., Parsekar, S. S., \& Nair, S. N. (2014). An epidemiological overview of child sexual abuse. Journal of Family Medicine and Primary Care, 3(4), 430.

Taner, Y., Bahar, G. (2004). Çocuk istismarı ve ihmali, psikiyatrik yönleri, Hacettepe Tıp Dergisi, 35: 82-85. 
Tan, M. (1991). Öğretmen Dayağı. (Editör: Konanç, E., Gürkaynak, İ., Egemen, A.). Çocuk istismarl ve ihmalinin önlenmesi. Ankara: Gözde Repo Ofset.

Türkiye'de Çocuk İstismarı Raporu-2. ASUMA ve İMDAT (2018). 12.12.2018 http://imdat.org/wp-content/uploads/2018/05/RAPOR-\%C3\%87OCUK$\% \mathrm{C} 4 \%$ B0ST\%C4\%B0SMARI-tam.pdf

Oral K.Ü., Engin, P ve Büyükyazıcı, Z.(2010). Türkiye’ De Çocuk İstismarı Ve Aile İçi Şiddet Araştırmasi. 12.10.2018 tarihinde http://www.unicef.org.tr/files/bilgimerkezi/doc/cocuk-istismari-raporu-tr.pdf indirilmiştir

UNICEF (2017). A familiar face. 16.04.2018. https://data.unicef.org/resources/a-familiar-face/

Vatansever, Ü. , Duran, R. ve Yolsal E. (2004). Pediatrik acilde çocuk istismarı ve ihmali olasılığını akılda tutalım. Türk Pediatri Dergisi, 39(120), 4.

Yunusoğlu, E., A. (2007). “Mersin'in kanayan yarası: “Sokakta çalışan çocuklar”. 16.04.2018. tarihinde http://www.mersin.edu.tr/icerik_p.php?hid=585 indirilmiştir. 